\title{
Urban Highway Roadside Soils and Shrub Plantings Enhanced by Surface-Applied and Incorporated Organic Amendments
}

\author{
Andy Bary, Rita L. Hummel, and Craig Cogger
}

\begin{abstract}
Degraded, highly compacted soils along roadsides present an inhospitable environment for trees and shrubs and lead to the failure of urban landscapes. Developing and testing practices to ameliorate urban soils, thereby improving plant growth and survival, is essential. This research compared the effects of waste-derived soil amendments on woody landscape plants and soil properties on a compacted highway roadside in Tacoma, Washington, U.S., and compared surface application versus incorporation of amendments. Treatments included yard debris compost (surface-applied and incorporated), biosolids blend (surfaceapplied and incorporated), and worm castings (surface-applied only), plus a control with no amendments. Amendments were applied $8 \mathrm{~cm}$ deep, and incorporated to a 10-15 cm depth on the tilled plots. An 8-cm layer of bark mulch was blown onto all plots, including the control. Rhus aromatica, Symphoricarpos orbiculatus, and Mahonia aquifolium were transplanted from 3.8 L containers in March 2007. One year later, soil under the mulch/amendments was analyzed for bulk density, total carbon, and nitrogen. Plant growth and survival was evaluated for three years. Incorporating soil amendments reduced bulk density by $>50 \%$ and increased soil $\mathrm{C}$ and $\mathrm{N}$ tenfold in the incorporated zone. Soil properties within the surface and control treatments or within the incorporated treatments were not different. All amendments significantly improved plant growth in comparison to the bark mulch control, in the order worm castings $\geq$ biosolids blend $\geq$ yard debris compost. Neither plant growth nor plant survival was affected by surface application versus incorporation, and plant roots remained confined to the amended zone.

Key Words. Bark; Biomass; Biosolids; Compost; Coralberry; Fragrant Sumac; Highway; Mahonia aquifolium; Mulch; Oregon Grape; Rhus aromatica; Roadside; Symphoricarpos orbiculatus; Total Soil Carbon; Total Soil Nitrogen; Urban Soils; Vermicompost; Washington; Worm Castings; Yard Debris.
\end{abstract}

Construction practices related to urban development typically leave a degraded, highly compacted soil environment that is detrimental to the growth of trees and shrubs (Alberty et al. 1984; Grabosky and Bassuk 1995; Jim 1998b; Scharenbroch et al. 2005; Chen et al. 2014; Watson et al. 2014a). Foster and Blaine (1978) estimated the average life span of street trees in urban neighborhoods to be only 10 years, and trees often fail during the first year or two following transplant. The main cause of these failures is due to an urban soil environment that impedes or prevents root growth (Patterson 1977; Watson et al. 2014a). After inspecting 80 roadside soil pits in urban Hong Kong, Jim (1998a) selected a representative site and conducted detailed analyses of the soil physical and chemical properties. Jim found heavy compaction, poor structure, and low levels of porosity, concluding that urban roadside sites are particularly stressful for tree growth with multiple soil problems that impair root growth and diminish vigor.

In the past 40 years, a number of studies have been conducted in an effort to determine optimal practices for restoring the urban soil environment so that it will support healthy tree and shrub growth (Whitcomb 1979; Day and Bassuk 1994; Gilman 2004; Cogger 2005; Scharenbroch 2009; Watson et al. 2014a). Much of this research has focused on using organic amendments to ameliorate the negative effects of urban and suburban development on the soil environment (Cogger 2005). Studies where organic soil amendments were mixed only 
into the planting-hole backfill soil have typically shown no consistent improvement in the growth and establishment of woody plants (Schulte and Whitcomb 1975; Hummel and Johnson 1985; Gilman 2004; Cogger 2005). When organic amendments are mixed into the entire landscape planting area, woody plant growth responses have been more positive. For example, amending planting beds by incorporating yard waste compost into the top $18 \mathrm{~cm}$ of a sandy soil improved azalea shoot and root growth (Beeson and Keller 2001). Incorporation of peat moss or pine bark into the entire planting bed to a depth of $20 \mathrm{~cm}$ improved growth and survival of one-year-old seedling mountain laurel in a clay soil (Bir and Ranney 1991).

Organic mulches applied to the surface of the soil have been shown to have a beneficial effect on soil properties and plant growth (Chalker-Scott 2007; Scharenbroch 2009). Because there are sites where incorporation of soil amendments by mixing is difficult if not impossible (steep roadsides, rocky subsoils), research has begun to focus on the potential for improving degraded urban soils and hence plant survival and growth by applying organic matter to the soil surface. Scharenbroch and Watson (2014) compared a compost topdressing to a wood-chip mulch treatment and found both improved tree growth and soil quality in a compacted urban soil. They called for future research to examine the effectiveness of combining those two treatments. Research with redosier dogwood in an agricultural soil (Cogger et al. 2008) compared surface-applied compost (topdressed) to soil-incorporated compost with and without a bark mulch layer and determined that surface application of compost could improve soil and plant qualities when incorporation was not feasible. In that study, application of bark mulch over either the incorporated or surfaceapplied compost was beneficial, but the efficacy on a compacted urban soil had yet to be tested.

The current study is a follow-up to Cogger et al. (2008). It is focused on the compacted, highly degraded soil environment typically found along urban highway roadsides. Two systems used by the Washington State Department of Transportation (WSDOT) were compared: amendment incorporated into the soil and covered by bark mulch, and amendment applied to the undisturbed soil surface, then covered by bark mulch. The objec- tives of this research were 1) to compare the effects of organic waste-derived soil amendments on woody landscape plant survival and growth and soil properties on a highly compacted highway roadside landscape; and 2) to determine if amendment incorporation benefitted plant growth and survival compared with surface application.

\section{MATERIALS AND METHODS}

\section{Site}

The study site was along a recently graded highway roadside in Tacoma, Washington, U.S., following construction but before landscaping. The $\mathrm{A}$ and $\mathrm{B}$ soil horizons were removed during construction, and the site was graded, leaving a highly compacted glacial outwash substratum with a texture of very gravelly sand (30\% gravel and rocks). The site had a southwest exposure adjacent to a sound barrier and received runoff from the surrounding landscape, resulting in wet conditions following winter rains.

Tacoma has a pacific northwest maritime climate, with cool, wet winters and mild dry summers. Mean December temperature is $5^{\circ} \mathrm{C}$, mean July temperature is $19^{\circ} \mathrm{C}$, and mean annual precipitation is $996 \mathrm{~mm}$ (Tacoma, WA 1981-2010 normals). July and August are the driest months, averaging $20 \mathrm{~mm}$ of precipitation each month.

\section{Organic Amendments}

Organic amendments used in the experiment included yard debris compost, a biosolids-sawdust blend, and worm castings (Table 1) obtained from commercial sources. The yard debris compost was produced in intensively managed, aerated turned piles under cover, with a six-week composting time. Feedstocks included woody trimmings, leaves, weeds, and grass clippings. The biosolids blend was a mixture of one part Class A biosolids cake, from the City of Tacoma, and four parts sawdust. The worm castings were produced using separated dairy solids as feedstocks and redworms (Eisenia fetida) for processing.

All plots were mulched with bark, following standard WSDOT highway roadside landscape practices. The bark mulch was Douglas-fir (Pseudotsuga menziesii) bark, ground to meet the WSDOT (2006) mulch specification of 95\%, passing a $3.8 \mathrm{~cm}$ (U.S. No.2) sieve and $\leq 55 \%$ 
passing a $0.64 \mathrm{~cm}$ (U.S. No. 4) sieve. The bark C:N ratio was 188 with total $\mathrm{N}$ of $2.5 \mathrm{~g} \cdot \mathrm{kg}^{-1}$.

Amendment total $\mathrm{C}$ and $\mathrm{N}$ were determined using a combustion analyzer (Gavlak et al. 2005). Amendment nitrate- $\mathrm{N}$ and ammonium $\mathrm{N}$ were extracted with $1 \mathrm{M} \mathrm{KCl}$. Nitrate was determined by an automated $\mathrm{Cd}$ reduction method, and ammonium by colorimetric analysis on a flowinjection analyzer (Gavlak et al. 2005). Moisture was determined by drying at $105^{\circ} \mathrm{C}$, and as is amendment bulk density estimated using the dropped-bucket method adapted from TMECC (2001). A tared and measured 18.9-L bucket was filled to the one-third mark with amendment, then dropped 10 times from a height of $30 \mathrm{~cm}$ to compact the sample. More amendment was added to the bucket to fill it to the two-thirds mark (and the dropping procedure repeated), and then to the full 18.9-L mark (and the dropping repeated again). A final addition of amendment filled the bucket back to the full mark, and the bucket was weighed without additional dropping. Amendment chemical characteristics are reported in Table 1.

\section{Experimental Design and Installation}

The experiment was a randomized complete block with six treatments and four replicates. Treatments included yard debris compost, surface-applied and incorporated; biosolids blend, surfaceapplied and incorporated; worm castings, surfaceapplied only; and a soil-only control. Plot size was $3 \mathrm{~m} \times 5 \mathrm{~m}$. An incorporated worm castings treatment was not included because insufficient material was available for this treatment.

Amendments were applied at a depth of $8 \mathrm{~cm}$ on 28 February 2007 , and tilled to a depth of $10-15$ $\mathrm{cm}$ on 07 March 2007 on the incorporated plots only, using a rototiller mounted on a small 4 -wheel drive tractor. An 8-cm layer of bark mulch was blown onto all plots, including the control plots.

Three shrub species typically used by the WSDOT in roadside settings were transplanted on 22 March 2007. Fragrant sumac (Rhus aromatica) and coralberry (Symphoricarpos orbiculatus) are deciduous shrubs native throughout the eastern and central United States, while Oregon grape (Mahonia aquifolium) is a west-coast-native evergreen shrub (USDA NCRS Plants Database 2015). The fragrant sumac cultivar 'Gro-Low' was used in this experiment. All three are drought-tolerant species adapted to a wide range of soil types (Pojar and MacKinnon 1994; Missouri Botanical Garden 2015b). Plants grown in 3.8-L containers were obtained from a local nursery. Transplanting was done by a WSDOT crew using a $25.4 \mathrm{~cm}$ diameter power auger to drill through the mulch and soil to a depth of $20-23 \mathrm{~cm}$. Plants were then removed from the containers, and the undisturbed root systems were placed in the planting holes and backfilled with the material removed by the power auger. Five plants of each species were planted in each plot for a total of 15 plants per plot. Plants were spaced 1 $\mathrm{m}$ apart. Because of a shortage of Oregon grape plants, three plots (one each of yard debris surface, yard debris incorporated, and worm castings) had fragrant sumac planted in place of the Oregon grape. Plants were watered once at transplant, then received no irrigation other than natural rainfall.

\section{Soil and Plant Measurements}

Soils were sampled in March 2008 and analyzed for total $\mathrm{C}$ and total $\mathrm{N}$ as described for the

Table 1. Soil amendment characteristics and application rates, mean and standard deviation of $\mathrm{C}, \mathrm{N}$, moisture, and bulk density, along with mean $\mathrm{C}: \mathrm{N}$, ammonium, and nitrate- $\mathrm{N}$.

\begin{tabular}{llll}
\hline & $\begin{array}{l}\text { Yard debris } \\
\text { compost }\end{array}$ & Biosolids blend \\
\hline Total C $\left(\mathrm{g} \mathrm{kg}^{-1}\right)$ & $440 \pm 29$ & $385 \pm 11$ & $381 \pm 16$ \\
Total N $\left(\mathrm{g} \mathrm{kg}^{-1}\right)$ & $12.5 \pm 0.3$ & $11.7 \pm 1.0$ & $18.9 \pm 1.2$ \\
Ammonium N $\left(\mathrm{g} \mathrm{kg}^{-1}\right)$ & $<0.1$ & 0.4 & $<.2$ \\
Nitrate N $\left(\mathrm{g} \mathrm{kg}^{-1}\right)$ & $<0.1$ & $<0.1$ & 23 \\
C:N & 35 & $53.0 \pm 0.3$ & 20 \\
Moisture $(\%)$ & $58.4 \pm 0.1$ & $465 \pm 4$ & $81.6 \pm 0.7$ \\
Bulk density $\left(\mathrm{kg} \mathrm{m}^{-3}\right)$ & $405 \pm 45$ & 8 & $742 \pm 79$ \\
Application rate $(\mathrm{cm})$ & 8 & 155 & 8 \\
Application rate $(\mathrm{Mg} \mathrm{ha})$ & 153 & 109 & \\
\hline
\end{tabular}

${ }^{\mathrm{z}}$ Samples per amendment for each measurement $(\mathrm{n}=3)$.

${ }^{\mathrm{y}}$ Bulk density was measured on as-is samples without drying. 
amendments. Overlying bark mulch and surfaceapplied amendments were removed before sampling. The soil was too compact and rocky for collection with an auger, so samples were collected with a spade and trowel from the 0 to 15 $\mathrm{cm}$ depth below the mulch layer. Six samples were randomly collected per plot and composited.

Soil bulk density was measured using an excavation method adapted from Grossman and Reinsch (2002), because the soil was too compact and rocky for standard cores. Holes were excavated with a trowel, and the hole lined with flexible plastic wrap. Water was measured into the hole to estimate the volume. The excavated soil (including gravel and rocks) was oven dried to determine mass. Three excavations were made and averaged per plot.

Plant survival was determined in November 2007, September 2008, and September 2009 by counting live and dead plants of each species in each plot. Plant height (tallest shoot) and width (widest and narrowest) were measured on all living plants in 2008 and 2009 at the same time as plant survival. A shootgrowth index was calculated as follows: [ $(\{$ widest width + narrowest width $\} / 2)+$ height $] / 2$.

The experiment ended in February 2010, when the site was slated to be disturbed by pending WSDOT construction. Before the site was disturbed, the aboveground portions of all live plants were harvested, oven dried at $55^{\circ} \mathrm{C}$, and weighed to determine dry biomass. In addition, root systems of fragrant sumac were removed, washed, and lengths of the three longest roots measured. The entire root mass was oven dried and weighed.

\section{Data Analysis}

Soil C, N, and bulk density, and plant survival, shoot-growth index, biomass, and root measurements were analyzed with SAS version 9.4 (SAS Institute, Cary, North Carolina, U.S.) as a randomized complete block design using PROC GLM. Shoot-growth index and root length were square root transformed, and aboveground biomass data were $\log$ transformed to meet assumptions of normality. Means were back transformed for reporting. Root biomass and survival were analyzed without transformation. Soil data showed bimodal distributions, and each mode of the distributions was analyzed separately without transformation.
Mean separations were done using LSD with the Tukey-Kramer adjustment at the $P=0.05$ significance level. Orthogonal contrasts were used to compare the effects of surface application versus incorporation of amendments (biosolids blend and yard debris compost) on plant growth and survival.

\section{RESULTS AND DISCUSSION}

\section{Soil C, N, and Bulk Density}

Soil differences between the surface (including the bark-mulch-only control) and incorporatedamendment treatments were so large, that the data for soil total C, total $\mathrm{N}$, and bulk density all fell into bimodal distributions, as noted in the data analysis. Mean bulk density in the incorporated treatments was less than half the bulk density in the surface-applied and control treatments, whereas mean total $\mathrm{C}$ was more than 12 times as great and mean total N, 10 times as great in the incorporated treatments as in the surface and bark mulch control treatments (Table 2).

There were no significant differences for any of the soil properties within the surface and control treatments or within the incorporated treatments (Table 2). The lack of difference within the surface-applied and control treatments indicates that little if any mixing of the surface-applied amendments or the bark mulch of the control treatment and the underlying native material occurred in the first year after application. In contrast, Cogger et al. (2008) observed evidence of mixing of surfaceapplied compost into uncompacted soil, as shown by reduced bulk density and visual presence of organic matter in the underlying soil.

Bulk densities measured in the native material in the control and surface-applied plots were unusually high, even for urban soils. Jim (1998b) measured an average bulk density of $1.65 \mathrm{Mg} \mathrm{m}^{-3}$ with a maximum of $2.63 \mathrm{Mg} \mathrm{m}^{-3}$ in 100 soil samples taken from 25 roadside locations in urban Hong Kong. Jim indicated that roadside urban soils are the most restrictive of the urban soils for plant growth. Results from the current study reflect the high degree of compaction at the roadside site, but may also be influenced by the bulk density measurement method. For the excavation method 
for determining bulk density, soil volume is measured as the volume of water poured into the hole where soil was removed. Accurate volume relies on a completely level surface of the hole, which was difficult to achieve in the compacted and gravelly native material. A nonlevel surface could result in a smaller volume measurement, and a larger calculated bulk density. Nonetheless, compaction was the dominant feature of the native material at the site.

\section{Plant Survival and Growth}

Analysis-of-Variance results for plant survival, shoot-growth index, aboveground biomass, and root measurements are summarized in Table 3 . Results show significant effects of amendment and year on shoot-growth index for all three shrub species, and on survival of fragrant sumac. No significant year $\times$ amendment interactions occurred, so only main effects are discussed below. Orthogonal contrasts for surface-applied versus incorporated amendments were only significant for shoot-growth index of fragrant sumac and Oregon grape; all other contrasts were not significant.

\section{Survival}

Overall, plant survival was high, despite the compacted soil at the site. Only fragrant sumac showed a significant decline in survival between year one and year two of the experiment, from $99 \%$ at the end of the first growing season (2007) to $79 \%$ in 2008 (Table 4). Fragrant sumac survival in the control treatment $(66 \%)$ was significantly less than in the amended treatments (85\%-92\%) (Table 5). Nearly all of the Oregon grape plants survived the experiment, with an average 97\% survival by 2009, and no significant change over time (Table $4)$. Oregon grape survival by amendment treatment ranged from $93 \%$ to $100 \%$ (Table 5), but differences were not significant at $P=0.05$ (Table $3)$. Survival of coralberry also showed no significant differences among treatments or over time (Table 3). Although not significant due to variability within treatments, coralberry survival tended to decline with time and was $79 \%$ by 2009 (Table 4). Results of orthogonal contrasts indicated survival differences between surface-applied and incorporated amendments were not significant for any of the shrub species (Table 3 ). In this ex-

Table 2. Soil bulk density, total carbon, and total $\mathrm{N}$ measured beneath the mulch layer ( 0 to $15 \mathrm{~cm}$ soil depth) in March 2008, one year following treatment application.

\begin{tabular}{|c|c|c|c|c|}
\hline & \multicolumn{2}{|c|}{$\begin{array}{l}\text { Control and surface } \\
\text { applied treatments }\end{array}$} & \multicolumn{2}{|c|}{$\begin{array}{l}\text { Incorporated } \\
\text { treatments }\end{array}$} \\
\hline & Mean & $\begin{array}{l}\text { ANOVA } \\
P \text {-value }\end{array}$ & Mean & $\begin{array}{l}\text { ANOVA } \\
P \text {-value }\end{array}$ \\
\hline Bulk density ${ }^{\mathrm{z}}\left(\mathrm{Mg} \mathrm{m}^{-3}\right)$ & 2.23 & $0.85^{y}$ & 0.93 & $0.69^{x}$ \\
\hline Total Cw $\left(\mathrm{g} \mathrm{kg}^{-1}\right)$ & 0.40 & 0.37 & 5.10 & 0.61 \\
\hline Total Nw $\left(\mathrm{g} \mathrm{kg}^{-1}\right)$ & 0.02 & 0.14 & 0.20 & 0.87 \\
\hline
\end{tabular}

${ }^{\mathrm{z}}$ Samples per plot (four replicate plots) for bulk density $(\mathrm{n}=3)$.

y Control and surface applications were analyzed separately because distribution was bimodal.

${ }^{\mathrm{x}}$ Incorporated treatments were analyzed separately because data distribution was bimodal.

${ }^{\mathrm{w}} \mathrm{n}=$ one composite sample per plot (four replicate plots) for $\mathrm{C}$ and $\mathrm{N}$.

Table 3. Analysis-of-Variance results for plant survival shoot-growth index, aboveground biomass, root biomass, and root length of three shrub species grown for three years in amended soil along an urban highway roadside.

\begin{tabular}{|c|c|c|c|c|c|c|c|c|c|c|c|}
\hline \multirow[t]{2}{*}{ Sources of variation } & \multicolumn{3}{|l|}{ Survival } & \multicolumn{3}{|c|}{ Shoot-growth index } & \multicolumn{3}{|c|}{ Aboveground biomass } & Root biomass & \multirow{2}{*}{ Root length } \\
\hline & $\begin{array}{l}\text { Fragrant } \\
\text { sumac }\end{array}$ & Coralberry & $\begin{array}{l}\text { Oregon } \\
\text { grape }\end{array}$ & $\begin{array}{l}\text { Fragrant } \\
\text { sumac }\end{array}$ & Coralberry & $\begin{array}{l}\text { Oregon } \\
\text { grape }\end{array}$ & $\begin{array}{l}\text { Fragrant } \\
\text { sumac }\end{array}$ & Coralberry & $\begin{array}{l}\text { Oregon } \\
\text { grape }\end{array}$ & Fragran & \\
\hline Amendment & $* * * z$ & 0.06 & 0.06 & $* * *$ & $* * *$ & $* * *$ & $* * *$ & $* * *$ & $* * *$ & $* * *$ & * \\
\hline Year & $* * *$ & 0.21 & 0.41 & $* * *$ & $* * *$ & $* * *$ & - & - & - & - & - \\
\hline Year $\times$ amendment & 0.06 & 0.99 & 0.94 & 0.81 & 0.53 & 0.29 & - & - & - & - & - \\
\hline $\begin{array}{l}\text { Surface versus } \\
\text { incorporatedy }\end{array}$ & 0.18 & 0.35 & 0.16 & * & 0.47 & * & 0.41 & 0.37 & 0.19 & 0.48 & 0.86 \\
\hline
\end{tabular}

${ }^{z}$ Single $\left(^{*}\right)$ and triple $\left({ }^{* * *}\right)$ asterisks indicate significance at $P<0.05$ and $P<0.001$, respectively. $P$-values are shown for non-significant $(P=0.05)$ comparisons.

y Orthogonal contrasts used to determine significance of surface application versus incorporation of biosolids blend and yard debris compost amendments. 
periment, plant survival was typically high, even though soil at the site was highly compacted and no supplemental irrigation was provided.

\section{Shoot growth}

Plants increased significantly in size during the third growing season. Shoot-growth indices of fragrant sumac, coralberry, and Oregon grape

Table 4. Survival and shoot-growth index of three shrub species grown in amended soil along an urban highway roadside for three years. Survival, at the end of each growing season, and shoot growth, in years two and three, are averaged over all soil amendment treatments.

\begin{tabular}{|c|c|c|c|}
\hline Species & Year & $\begin{array}{l}\text { Survival } \\
(\%)\end{array}$ & $\begin{array}{l}\text { Shoot-growth } \\
\text { index }^{2}(\mathrm{~cm})\end{array}$ \\
\hline \multirow[t]{3}{*}{ Fragrant sumac } & 2007 & $99 \mathrm{a}^{y}$ & -- \\
\hline & 2008 & $79 \mathrm{~b}$ & $67 \mathrm{~b}$ \\
\hline & 2009 & $78 \mathrm{~b}$ & $78 \mathrm{a}$ \\
\hline \multirow[t]{3}{*}{ Coralberry } & 2007 & $89 \mathrm{a}$ & -- \\
\hline & 2008 & $84 \mathrm{a}$ & $109 \mathrm{~b}$ \\
\hline & 2009 & $79 \mathrm{a}$ & $139 \mathrm{a}$ \\
\hline \multirow[t]{3}{*}{ Oregon grape } & 2007 & $99 \mathrm{a}$ & -- \\
\hline & 2008 & $99 \mathrm{a}$ & $26 \mathrm{~b}$ \\
\hline & 2009 & $97 \mathrm{a}$ & $32 \mathrm{a}$ \\
\hline
\end{tabular}

${ }^{2}$ Shoot-Growth Index $=[$ (widest width + narrowest width $) / 2+$ height $] / 2$. ${ }^{y}$ Means within a species followed by different letters are significantly different $(P<0.05)$ by Tukey-Kramer adjusted LSD; $\mathrm{n}=135$ for fragrant sumac, 120 for coralberry, and 105 for Oregon grape. were $16 \%, 27 \%$, and $23 \%$ larger, respectively, on September 2009 than in September 2008 (Table 4). All amendments significantly improved plant growth in comparison to the control for all three species (Table 3; Table 5). Coralberry showed the greatest overall growth, followed by fragrant sumac and Oregon grape. For fragrant sumac and coralberry, growth response was in the order: worm castings $\geq$ biosolids blend $\geq$ yard debris compost > control, as measured by shoot-growth index and aboveground biomass (Table 5). Plant biomass for the worm castings treatment was more than 10 times the biomass of the control for both fragrant sumac and coralberry. Oregon grape growth was similar, except that the response to worm castings was not as large as for fragrant sumac and coralberry, and biomass for the yard debris compost treatment was not significantly different from the control. The difference in Oregon grape biomass for the treatment producing the largest plants (biosolids blend surface) compared with the control was a factor of four (Table 5).

Differential growth response among amendments was most likely the result of differences in nitrogen availability. None of the materials had much immediately available inorganic $\mathrm{N}$ (Table 1).

Table 5. Survival, shoot-growth index, and aboveground biomass response of fragrant sumac, coralberry, and Oregon grape; and root length and root biomass response of fragrant sumac to organic soil amendments that were either surface-applied or incorporated. Douglas-fir bark mulch was applied to the controls and all amended plots. Plants were grown along an urban highway roadside for three years.

\begin{tabular}{|c|c|c|c|c|c|c|c|}
\hline Species & Amendment & $\begin{array}{l}\text { Application } \\
\text { method }\end{array}$ & $\begin{array}{l}\text { Survival }^{\mathrm{z}} \\
(\%)\end{array}$ & $\begin{array}{l}\text { Shoot-growth } \\
\text { index }{ }^{y}(\mathrm{~cm})\end{array}$ & $\begin{array}{l}\text { Aboveground } \\
\text { biomass }(\mathrm{g})\end{array}$ & $\begin{array}{l}\text { Root } \\
\text { length }(\mathrm{cm})\end{array}$ & $\begin{array}{l}\text { Root } \\
\text { biomass (g) }\end{array}$ \\
\hline \multirow[t]{6}{*}{ Fragrant sumac } & \multirow[t]{2}{*}{ Yard debris compost } & Incorporated & $92 a^{x}$ & $71 \mathrm{c}$ & $90 \mathrm{~b}$ & $107 \mathrm{ab}$ & $158 \mathrm{bc}$ \\
\hline & & Surface & $88 \mathrm{a}$ & $72 \mathrm{bc}$ & $109 \mathrm{ab}$ & $106 \mathrm{ab}$ & $171 \mathrm{bc}$ \\
\hline & \multirow{2}{*}{ Biosolids blend } & Incorporated & $90 \mathrm{a}$ & $72 \mathrm{bc}$ & $132 \mathrm{ab}$ & $111 \mathrm{ab}$ & $253 \mathrm{~b}$ \\
\hline & & Surface & $85 \mathrm{a}$ & $84 \mathrm{ab}$ & $156 \mathrm{ab}$ & $116 \mathrm{ab}$ & $280 \mathrm{ab}$ \\
\hline & Worm castings & Surface & $91 \mathrm{a}$ & $97 \mathrm{a}$ & $251 \mathrm{a}$ & $130 \mathrm{a}$ & $388 \mathrm{a}$ \\
\hline & Control & & $66 \mathrm{~b}$ & $44 \mathrm{~d}$ & $19 \mathrm{c}$ & $75 \mathrm{~b}$ & $55 \mathrm{c}$ \\
\hline \multirow[t]{6}{*}{ Coralberry } & \multirow[t]{2}{*}{ Yard debris compost } & Incorporated & $89 a$ & $113 \mathrm{c}$ & $218 \mathrm{~b}$ & & \\
\hline & & Surface & $90 \mathrm{a}$ & $123 \mathrm{bc}$ & $321 \mathrm{ab}$ & & \\
\hline & \multirow[t]{2}{*}{ Biosolids blend } & Incorporated & $83 a$ & $142 \mathrm{ab}$ & $458 \mathrm{ab}$ & & \\
\hline & & Surface & $71 \mathrm{a}$ & $141 \mathrm{ab}$ & $468 \mathrm{ab}$ & & \\
\hline & Worm castings & Surface & $91 \mathrm{a}$ & $160 \mathrm{a}$ & $704 \mathrm{a}$ & & \\
\hline & Control & & $78 \mathrm{a}$ & $75 \mathrm{~d}$ & $48 \mathrm{c}$ & & \\
\hline \multirow[t]{6}{*}{ Oregon grape } & \multirow[t]{2}{*}{ Yard debris compost } & Incorporated & $98 \mathrm{a}$ & $25 \mathrm{~b}$ & $32 \mathrm{bc}$ & & \\
\hline & & Surface & $93 \mathrm{a}$ & $31 \mathrm{ab}$ & $36 \mathrm{bc}$ & & \\
\hline & \multirow[t]{2}{*}{ Biosolids blend } & Incorporated & $100 \mathrm{a}$ & $33 a$ & $64 \mathrm{ab}$ & & \\
\hline & & Surface & $100 \mathrm{a}$ & $35 \mathrm{a}$ & $84 \mathrm{a}$ & & \\
\hline & Worm castings & Surface & $100 \mathrm{a}$ & $34 \mathrm{a}$ & $60 \mathrm{ab}$ & & \\
\hline & Control & & $98 \mathrm{a}$ & $18 \mathrm{c}$ & $19 c$ & & \\
\hline
\end{tabular}

\footnotetext{
${ }^{\mathrm{z}}$ Survival and shoot-growth index were measured September 2009; aboveground biomass, root length, and root biomass were measured February 2010.

y Shoot-Growth Index $=[$ (widest width + narrowest width $) / 2+$ height $] / 2$.

${ }^{\mathrm{x}}$ Means within a species and column followed by different letters are significantly different $(P<0.05)$ by Tukey-Kramer adjusted LSD; $\mathrm{n}=20$ for all treatments except yard debris compost incorporated and surface, and worm castings surface where $\mathrm{n}=25$ for fragrant sumac and $\mathrm{n}=15$ for Oregon grape.
} 
The worm castings had the lowest C:N ratio (20:1), which is low enough to provide slow release of $\mathrm{N}$ during each growing season (Cogger 2005). The yard debris compost used in this experiment had a C:N ratio of $35: 1$, which is likely to immobilize $\mathrm{N}$ the first year, and release small amounts of $\mathrm{N}$ in subsequent years (Sullivan et al. 2002). Thus, nitrogen availability likely was a cause of the differences in plant growth between the yard debris compost and worm castings. The biosolids blend also had a high C:N ratio (33:1), but this did not appear to cause short-term $\mathrm{N}$ immobilization. This is because the blend was a mixture and not a compost, and the biosolids component (C:N of 9:1) (Gilmour et al. 2003) would release $\mathrm{N}$ in the short run.

The orthogonal contrasts showed a significant difference in shoot-growth index between surface and incorporated amendment treatments for fragrant sumac and Oregon grape (Table 3). Differences were small, but in both cases the surfaceapplication treatment had a greater shoot-growth index as averaged over the biosolids blend and yard debris compost amendments. Aboveground biomass of all three species was also consistently larger for surface-applied treatments, but the differences were not significant (Table 3; Table 5).

\section{Roots}

Root length and biomass were determined only for fragrant sumac (Table 3). Roots grew from the original planting hole and spread throughout the amended layers, but there was little to no root penetration of the compacted native mineral material. Although it is commonly recommended that the circling roots of container-grown trees and shrubs be cut or shaved before planting to prevent stemgirdling roots from developing (Ophardt and Hummel 2011; Watson et al. 2014b), root systems of the container-grown shrubs in this study were left intact at transplant. At the end of one growing season, Blessing and Dana (1987) found that vertically cutting the root systems of $3.8 \mathrm{~L}$ container-grown Chinese juniper at transplant reduced new root growth in a heavy silty clay soil compared to undisturbed root systems. In the current study, roots were observed growing throughout the amended zones in the surface-applied and incorporated treatments, but were growing only in the original planting hole and the bark mulch layer of the con- trol treatment. Fragrant sumac had greater root length in worm castings than the control treatment, but no other differences were significant (Table 5). Both worm castings and the biosolids blend had greater root biomass than the control treatment.

\section{Surface versus incorporated treatments}

It is notable that no significant positive benefits to plant growth were observed when the amendments were incorporated into the soil rather than left on the soil surface, since the rooting zone was not as deep in the surface treatments. Apparently, the increased depth of the rooting zone in the incorporated treatment (incorporated compost + bark mulch $=20-23 \mathrm{~cm}$ initial depth) was not enough to improve plant growth or survival compared with the surface-applied amendments (surface compost + bark mulch $=16 \mathrm{~cm}$ initial depth). Cogger et al. (2008) found application method had no significant effect on redosier dogwood growth during a five-year period following surface versus incorporation of yard debris compost to an uncompacted soil. Scharenbroch and Watson (2014) observed increased growth of river birch and red maple trees with surfaceapplied compost and wood-chip mulch in compacted urban soils, and concluded topdressings of compost and wood-chip mulches should be used to grow trees in compact urban soils.

\section{Amendment type}

A total of eleven survival and growth measurements were made for the three shrub species, fragrant sumac, coralberry, and Oregon grape, and the worm castings treatment was statistically among the best for all 11 measurements (Table 5). The biosolids treatment, whether surface-applied or soil-incorporated, was statistically among the best for nine of those measurements, nearly as good as worm castings. The only biosolids measurements not among the top rated were the incorporated fragrant sumac shoot-growth index and root biomass, but these measurements were significantly better than the control. In a microcosm study with honeylocust and sugar maple, biosolids were applied as a mulch to three different soils (i.e., silt loam, compacted clay, sand) and produced the greatest increases in tree growth for both species in all three soil types (Scharenbroch et al. 2013). The high 
cost of worm castings preclude their routine use along highway roadsides, but the biosolids blend is cost-competitive and delivered positive results.

\section{Implications for Urban Soil Manage- ment}

Application of organic amendments plus bark mulch significantly improved survival of fragrant sumac, and improved growth of all three species compared with an unamended, bark-mulch control along a highly compacted highway roadside. Incorporation of amendments did not improve survival or growth of any of the species in comparison to surface application, despite the additional benefit of decreased soil compaction, suggesting that the expense of incorporation is not necessary under similar conditions. Although the rate of plant growth differed among amendments, likely because of nitrogen availability, all amendments produced acceptable growth and survival over the three-year period of the study.

Acknowledgments. The authors thank Elizabeth Myhre and Bob Riley for their technical assistance in the field and laboratory. Financial support for this project was provided by the Northwest Biosolids Management Association; the City of Seattle, Washington, U.S.; and the Agricultural Research Center at Washington State University (USDA/NIFA Hatch Projects WNP3755 and 0722). The Washington State Department of Transportation provided plants, bark, worm castings, and labor to help with experiment installation. The City of Tacoma, Washington, U.S. supplied the biosolids blend, and LRI, Inc. provided the yard debris compost.

\section{LITERATURE CITED}

Alberty, C.A., H.M. Pellett, and D.H. Taylor. 1984. Characterization of soil compaction at construction sites and woody plant response. Journal of Environmental Horticulture 2:48-53.

Beeson, R.C., and K.G. Keller. 2001. Yard waste compost as a landscape soil amendment for azaleas. Journal of Environmental Horticulture 19:222-225.

Bir, R.E., and T.G. Ranney. 1991. The effect of organic soil amendments on the growth and development of Kalmia latifolia. Proceedings International Plant Propagators' Society 41:395-398.

Blessing, S.C., and M.N. Dana. 1987. Post-transplant root system expansion in Juniperus chinensis L. as influenced by production system, mechanical root disruption, and soil type. Journal of Environmental Horticulture 5:155-158.

Chalker-Scott, L. 2007. Impact of mulches on landscape plants and the environment-A review. Journal of Environmental Horticulture 25:239-249.

Chen, Y., S.D. Day, A.F. Wick, and K.J. McGuire. 2014. Influence of urban land development and subsequent soil rehabilitation on soil aggregates, carbon, and hydraulic conductivity. Science of the Total Environment 494:329-336.
Cogger, C.G. 2005. Potential compost benefits for restoration of soils disturbed by urban development. Compost Science and Utilization 13:243-251.

Cogger, C.G., R. Hummel, J. Hart, and A. Bary. 2008. Soil and redosier dogwood response to incorporated and surfaceapplied compost. HortScience 43:2143-2150.

Day, S.D., and N.L. Bassuk. 1994. A review of the effects of soil compaction and amelioration treatments on landscape trees. Journal of Arboriculture 20:9-17.

Foster, R.S., and J. Blaine. 1978. Urban tree survival: Trees in the sidewalk. Journal of Arboriculture 4:14-17.

Gavlak, R.G., D.A. Horneck, and R.O. Miller. 2005. Soil, plant, and water reference methods for the western region. Western Regional Extension Publication 125, third edition.

Gilman, E.F. 2004. Effects of amendments, soil additives, and irrigation on tree survival and growth. Journal of Arboriculture 30:301-311.

Gilmour, J.T., C.G. Cogger, L.W. Jacobs, G.K. Evanylo, and D.M. Sullivan. 2003. Decomposition and plant available $\mathrm{N}$ in biosolids: Laboratory studies, field, studies, and computer simulation. Journal of Environmental Quality 32:1498-1507.

Grabosky, J., and N. Bassuk. 1995. A new urban tree soil to safely increase rooting volumes under sidewalks. Journal of Arboriculture 21:187-201.

Grossman, R.B., and T.G. Reinsch. 2002. Bulk density and linear extensibility. p. 201-228. In: J.H. Dane and E.G. Topp (Eds.). Methods of soil analysis. Part 4. Physical methods. Soil Science Society of America. Book Series 5. SSSA, Madison, Wisconsin, U.S.

Hummel, R.L., and C.R. Johnson. 1985. Amended backfills: Their cost and effect on transplant growth and survival. Journal of Environmental Horticulture 3:76-79.

Jim, C.Y. 1998a. Physical and chemical properties of a Hong Kong roadside soil in relation to urban tree growth. Urban Ecosystems 2:171-181.

Jim, C.Y. 1998b. Urban soil characteristics and limitations for landscape planting in Hong Kong. Landscape and Urban Planning 40:235-249.

Missouri Botanical Garden. 2015a. Rhus aromatica 'Gro-Low' Accessed 24 February 2015. <www.missouribotanicalgarden. org/PlantFinder/PlantFinderDetails.aspx?kempercode $=\mathrm{f} 180>$

Missouri Botanical Garden. 2015b. Symphoricarpos orbiculatus. Accessed 24 February 2015. <www.missouribotanicalgarden. org/PlantFinder/PlantFinderDetails.aspx?kempercode $=\mathrm{f} 730>$

Ophardt, M.C., and R.L. Hummel. 2011. Planting Trees and Shrubs in the Landscape. FS047E. Washington State University Extension Fact Sheet. <http://cru.cahe.wsu.edu/CEPublications/ FS047E/FS047E.pdf>

Patterson, J.C. 1977. Soil compaction-Effects on urban vegetation. Journal of Arboriculture 3:161-167.

Pojar, J., and A. MacKinnon. (Eds.). 1994. Plants of the Pacific Northwest Coast. Lone Pine Publishing, Vancouver, British Columbia, Canada.

Scharenbroch, B.C. 2009. A meta-analysis of studies published in Arboriculture \& Urban Forestry relating to organic materials and impacts on soil, tree, and environmental properties. Arboriculture \& Urban Forestry 35:221-231.

Scharenbroch, B.C., and G.W. Watson. 2014. Wood chips and compost improve soil quality and increase growth of Acer rubrum and Betula nigra in compacted urban soil. Arboriculture \& Urban Forestry 40:319-331. 
Scharenbroch, B.C., E.N. Meza, M. Catania, and K. Fite. 2013. Biochar and biosolids increase tree growth and improve soil quality for urban landscapes. Journal of Environmental Quality 42:1372-1385.

Scharenbroch, B.C., J.E. Lloyd, and J.L. Johnson-Maynard. 2005. Distinguishing urban soils with physical, chemical, and biological properties. Pedobiologia 49:283-296.

Schulte, J.R., and C.E. Whitcomb. 1975. Effects of soil amendments and fertilizer levels on the establishment of silver maple. Journal of Arboriculture 1:192-195.

Sullivan, D.M., A.I. Bary, D.R. Thomas, S.C. Fransen, and C.G. Cogger. 2002. Food waste compost effects on fertilizer nitrogen efficiency, available nitrogen, and tall fescue yield. Soil Science Society of America Journal 66:154-161.

TMECC. 2001. Test methods for the examination of composting and compost. Composting Council Education and Research Foundation, Bethesda, Maryland, U.S.

USDA Natural Resource Conservation Service. Plants Database. 2015. Accessed 24 February 2015. <http://plants.usda.gov>

Washington State Department of Transportation. 2006. Standard Specifications for Road, Bridge, and Municipal Construction. M 41-10. <www.wsdot.wa.gov/publications/manuals/fulltext/ M41-10/SS2006.pdf>

Watson, G.W., A.M. Hewitt, M. Custic, and M. Lo. 2014a. The management of tree root systems in urban and suburban settings: A review of soil influence on root growth. Arboriculture \& Urban Forestry 40:193-217.

Watson, G.W., A.M. Hewitt, M. Custic, and M. Lo. 2014b. The management of tree root systems in urban and suburban settings II: A review of strategies to mitigate human impacts. Arboriculture \& Urban Forestry 40:249-271.

Whitcomb, C.E. 1979. Factors affecting the establishment of urban trees. Journal of Arboriculture 5:217-219.

\author{
Andy Bary \\ Department of Crop and Soil Sciences \\ Washington State University Puyallup Research and Extension \\ Center \\ 2606 West Pioneer \\ Puyallup, Washington 98371, U.S.

Rita L. Hummel (corresponding author)
Department of Horticulture
Washington State University Puyallup Research and Extension
Center
2606 West Pioneer
Puyallup, Washington 98371, U.S.
hummelrl@wsu.edu
Craig Cogger
Department of Crop and Soil Sciences
Washington State University Puyallup Research and Extension
Center
2606 West Pioneer
Puyallup, Washington 98371, U.S.

Résumé. Les sols dégradés, extrêmement compactés le long des routes offrent un environnement inhospitalier aux arbres et aux arbustes et contribuent à la dévaluation de paysages urbains. Le fait de développer et de tester de nouvelles pratiques pour améliorer les sols urbains, améliorant ainsi la croissance et la survie des plantes, est fondamental. Cette recherche a comparé les effets d'amendements de sol provenant de sous-produits de déchets sur des plantes ligneuses ornementales et les propriétés physico-chimiques d'un sol compacté le long d'une autoroute à Tacoma, Washington, ÉtatsUnis, puis a examiné les mérites de l'application en surface versus l'incorporation au sol des amendements. Les traitements comprenaient l'application d'un compost constitué de débris végétaux (application en surface et incorporation), un mélange de biosolides (application de surface et incorporation) et du vermicompost (application de surface seulement), ainsi que des parcelles témoins sans aucun amendement. Les amendements ont été appliqués sur une épaisseur de $8 \mathrm{~cm}$ et mélangés jusqu'à une profondeur de 10 à $15 \mathrm{~cm}$ pour les parcelles incorporées. Une couche de $8 \mathrm{~cm}$ de paillis d'écorce a été pulvérisée sur toutes les parcelles, incluant les parcelles témoins. Des plants de Rhus aromatica, (sumac aromatique), de Symphoricarpos orbiculatus (symphorine) et de Mahonia aquifolium (mahonia à feuilles de houx) cultivés en pots de $3,8 \mathrm{~L}$, ont été plantés en mars 2007. Un an plus tard, le sol des parcelles amendées et avec paillis a été analysé quant à sa densité volumétrique, son carbone total et son contenu en azote. La croissance et la survie des plantes ont été évaluées pendant trois années. L'incorporation des amendements de sol a réduit la densité volumétrique de plus de 50 $\%$ et a multiplié par dix la teneur en carbone et en azote dans les parcelles mélangées. Les propriétés du sol tant des parcelles avec application en surface et des parcelles témoins que celles avec incorporation d'amendements n'ont présenté aucune différence. Tous les amendements ont significativement amélioré la croissance des plantes par rapport aux parcelles témoins ne comportant que du paillis d'écorce, dans l'ordre le vermicompost $\geq$ le mélange de biosolides $\geq$ le compost de débris végétaux. Tant la croissance que la survie des plantes nont présenté de modification en lien avec l'application en surface versus l'incorporation. Noter que les racines des plantes sont demeurées confinées à la zone amendée.

Zusammenfassung. Zerstörte, hoch verdichtete Böden entlang den Straßen präsentieren eine ungastliche Umgebung für Bäume und Sträucher und führen zu deren Versagen in der urbanen Landschaft. Das Entwickeln und Testen von Praktiken zur Verbesserung von urbanen Böden und somit zur Steigerung des Pflanzenwachstums und Überlebens ist essentiell. Diese Forschung vergleicht die Auswirkungen von Bodenzuschlagsstoffen aus Abfall auf Gehölzpflanzen und Bodeneigenschaften auf einem verdichteten Straßenabschnitt in Tacoma, Washington,U.S. und vergleicht eine Oberflächenapplikation gegenüber einer Einarbeitung der $\mathrm{Zu}$ schlagstoffe. Die Behandlungen bestanden aus Gartenabfallkompost (oberflächlich und eingearbeitet), Klärschlamm (oberflächlich und eingearbeitet) und Wurmkacke (nur oberflächlich), plus einer Kontrolle ohne Zuschlagstoffe. Die Zuschlagstoffe wurden 8 $\mathrm{cm}$ hoch aufgetragen bzw. bis zu 10-15 cm tief eingearbeitet. Eine Abdeckung von $8 \mathrm{~cm}$ Rindenmulch wurde auf alle Stellen aufgetragen, einschließlich der Kontrolle. Rhus aromatica, Symphoricarpos orbiculatus, und Mahonia aquifolium wurden im März 2007 aus 3,8 1 Containern verpflanzt. Ein Jahr später wurde der Boden unter den Zuschlagstoffen bzw. dem Rindenmulch in Bezug auf Körperdichte, Kohlenstoffanteil und Stickstoffgehalt analysiert. Das Pflanzenwachstum und das Überleben wurde für drei Jahre bewertet. Das Einarbeiten von Bodenzuschlagstoffen reduzierte die Bodendichte um mehr als $50 \%$ und steigerte den C- und N-Gehalt um das Zehnfache in der bearbeiteten Fläche. Die Bodeneigenschaften innerhalb der Oberflächen- oder Einarbeitungsbehandlungen oder der Kontrollflächen unterschieden sich nicht. Alle Zuschlagstoffe 
verbesserten deutlich das Pflanzenwachstum im Vergleich zur Rindenmulchkontrolle in der Reihenfolge $\geq$ Wurmkacke $\geq$ Klärschlamm $\geq$ Gartenabfallkompost. Weder das Pflanzenwachstum noch die Überlebensrate wurde durch die Oberflächenapplikation versus Einarbeitung beeinflusst und die Pflanzenwurzeln blieben beschränkt auf die bearbeiteten Flächen.

Resumen. Los suelos degradados, altamente compactados, a lo largo de las carreteras presentan un ambiente inhóspito para los árboles y arbustos y conducen a la insuficiencia de los paisajes urbanos. Las prácticas de desarrollo y prueba son esenciales para modificar los suelos urbanos, mejorando de este modo el crecimiento de las plantas y la supervivencia. Esta investigación comparó los efectos de los mejoradores derivados de residuos del suelo en las plantas leñosas y las propiedades del suelo al borde de la carretera en Tacoma, Washington, EE.UU., comparando la aplicación superficial con a la incorporación de enmiendas. Los tratamientos incluyeron el compost de desechos de jardín (e incorporados aplicados en la superficie), mezcla de biosólidos (incorporados y aplicados en la superficie) y el humus de lombriz (aplicada solamente en la superficie), más un testigo sin enmiendas. Los mejoradores se aplicaron a $8 \mathrm{~cm}$ de profundidad, y se incorporan a una profundidad de 10-15 $\mathrm{cm}$ en las parcelas labradas. Se puso una capa de $8 \mathrm{~cm}$ de mantillo de corteza sobre todas las parcelas, incluyendo el control. Rhus aromatica, Symphoricarpos orbiculatus, y Mahonia aquifolium se trasplantaron a partir de contenedores de 3,8 L en marzo de 2007. Un año más tarde, el suelo bajo el mantillo/mejoradores se analizó para determinar la densidad aparente, carbono total y nitrógeno. El crecimiento de las plantas y la supervivencia se evaluó durante tres años. La incorporación de las enmiendas del suelo reduce la densidad aparente $>50 \%$ y aumentó el $\mathrm{C}$ y $\mathrm{N}$ del suelo diez veces en la zona que se incorporó. Las propiedades del suelo dentro de los tratamientos de superficie y de control o dentro de los tratamientos incorporados no fueron diferentes. Todas las enmiendas mejoraron significativamente el crecimiento de plantas en comparación con el control de mantillo de corteza, en el orden lombrices $\geq$ biosólidos de restos de compost $\geq$ compost de patio. Ni la supervivencia $n i$ el crecimiento de las plantas se vieron afectadas por la aplicación superficial frente a la incorporación y las raíces de las plantas se mantuvieron confinadas a la zona mejorada. 